\title{
Drought Trends in Balochistan
}

\author{
Falak Naz ${ }^{1, *} \mathbb{0}$, Ghulam Hussain Dars ${ }^{1, *} \mathbb{\infty}$, Kamran Ansari ${ }^{1}$, Shoaib Jamro ${ }^{1}(\mathbb{C}$ and \\ Nir Y. Krakauer 2 (D) \\ 1 U.S.-Pakistan Center for Advanced Studies in Water, Mehran University of Engineering and Technology, \\ Jamshoro 76090, Pakistan; kansari.uspcasw@faculty.muet.edu.pk (K.A.); jamroshoaib95@gmail.com (S.J.) \\ 2 Department of Civil Engineering and NOAA-CREST, City College of New York, New York, NY 10031, USA; \\ mail@nirkrakauer.net \\ * Correspondence: falaknazchanna@gmail.com (F.N.); ghdars.uspcasw@faculty.muet.edu.pk (G.H.D.)
}

Received: 30 December 2019; Accepted: 6 February 2020; Published: 10 February 2020

check for updates

Featured Application: The current study deals with the growing challenge of droughts in a changing climate. The analysis of drought trends in one of the most vulnerable regions in Pakistan and Balochistan reveals insights into the evolving characteristics of droughts in different parts of the region. The findings will prove useful for water resource managers.

\begin{abstract}
Drought is a severe threat, especially in the arid regions of Pakistan, such as the Balochistan Province. The aim of this study is to analyze drought trends in Balochistan using Standard Precipitation Index (SPI) at the 3-month accumulation timescale. The monthly rainfall data of 10 stations were collected from the Pakistan Meteorological Department (PMD) for 37 years (1980-2017). Drought trends were analyzed at each station using the Mann-Kendall test. The SPI identified extreme drought events in 1996, 2001, 2002, 2004, 2009, and 2014. Barkhan was the station that most frequently experienced extreme to severe drought events, as defined using SPI. A statistically significant decreasing precipitation trend was found in four stations (Dalbandin, Jiwani, Quetta, and Zhob). The analysis of drought characteristics showed Barkhan faced the most prolonged drought, of 22 months from 1999 to 2001. The findings from the present study can give guidance on how strategies of water management should be adjusted based on the changing patterns of droughts in the Balochistan Province.
\end{abstract}

Keywords: balochistan; pakistan; precipitation; SPI; mann kendall test; drought characteristics

\section{Introduction}

Pakistan is one of the most vulnerable countries due to climate change. The Global Climate Risk Index (GCRI) [1] has ranked Pakistan in the top 10 countries adversely affected by climate change. The GCRI has characterized extreme events based on the last 20 years of data (1998 to 2017). The major threats include rising temperatures, erratic rainfall patterns, sea-level rise, and extreme events (floods, droughts, and heatwaves). Drought is one of the most severe threats especially in the arid regions of Pakistan, such as the Balochistan Province. The adverse effects of climate change have worsened with time [2]. As stated in Reference [3], developing countries like Pakistan are more susceptible to climate change because of their lower adaptive capacities. With its arid geography and scarcity of resources, Pakistan is extremely exposed to the impacts of climate change [4]. The country has been suffering from increased severity and occurrence of meteorological hazards including floods, dry periods, extreme temperatures, and a water shortage $[5,6]$.

In Pakistan, droughts occur some four out of 10 years [7], with Balochistan province being one of the most vulnerable to hydrological threats due to arid climatic conditions [8]. The primary source of $85 \%$ population of Balochistan's income is agriculture [9]. This province has faced many severe 
droughts in the past, i.e., 1967-1969, 1971, 1973 to 1975, 1994, and 1998 to 2002, which had a drastic impact on livelihoods and its economy. These prolonged droughts destroyed nearly $80 \%$ of fruit orchards [10]. Rain-fed crop yields shrank and around two million animals died [11]. Moreover, frequent droughts along with high water withdrawal have led to considerable declines in the water table [12]. Heatwaves have also worsened in this region, which has increased the frequency of drought events and their severity [13]. Changes in climatic conditions may have a substantial impact on the hydrological cycle of Balochistan. Climate change is likely to disrupt the typical seasonal conditions in Balochistan, which results in an intense and longer summer, while the winters are expected to become shorter [14].

Several studies have been conducted to study droughts using different indices in Pakistan [8,10,15-21]. Drought severity was analyzed in Balochistan using Standard Precipitation Index (SPI). Researchers used precipitation data from 36 years (1975-2010) recorded at 23 rain-gauges. They found SPI to be a suitable index to investigate meteorological droughts over this region [10]. In another study [22], authors used rainfall data from 58 meteorological gauges from the years 1951-2014 to evaluate and compare the performance of 15 drought monitoring indices to examine drought conditions in Pakistan. They found SPI to be suitable among the rest of the indices to examine the dry-period status in the country. Authors in Reference [23] observed that SPI is an appropriate index to determine drought events during their research on investigating rainfall and droughts in South Central Asia, especially in Pakistan, from 1951-2010. Similarly, other studies used SPI to characterize droughts over Sindh [19,20], to examine spatiotemporal variability of dry periods in Pakistan [24], to monitor the seasonal droughts in Balochistan [16]. However, there have not been previous investigations using SPI to characterize droughts and their trends in the Balochistan province.

The main scope of this study was to characterize the meteorological droughts that occurred from 1980-2017 in different parts of Balochistan using SPI based on station data. In addition, the Mann-Kendall (M-K) trend test was applied to identify statistically significant trends in droughts. In this study, the characteristics of these historical drought occurrences are defined by indicators including duration of dry periods, its severity, intensity, and peak. The outcomes of the present study suggest that strategies of water resources management should be according to the changing patterns in drought in the Balochistan province.

\section{Methods}

\subsection{Study Area}

Balochistan is known as a mountainous and dry area of Pakistan, and its location in Pakistan is shown in Figure 1. It is located around $30^{\circ}$ north and $67^{\circ}$ east. The province is rugged and includes several plateaus of different heights. Geographically, the province consists of four zones: upper and lower highlands, plains, and deserts. These zones have different climates: In Plain zones summers are extremely hot, and winters are mild, whereas in upper plateaus summers are warm and cold winters, lower plateaus are hot and dry in summers and extremely cold in winters. Deserts are hot and dry $[10,16]$.

Monsoon winds bring summer rainfall, whereas westerly disturbances cause winter precipitation in the province. Westerly disturbances tend to travel east across the higher latitudes of the Balochistan, so that regions that are at $34-36^{\circ}$ north receive maximum rainfall. These westerly disturbances generate secondary precipitation in the lower areas of the province [16]. Balochistan receives 200 to $350 \mathrm{~mm}$ of annual precipitation. This annual amount may include snow in the winter and heavy rains in the summer [10]. In the summer, the temperature rises to $50{ }^{\circ} \mathrm{C}$ in plain areas of this province. The northeastern parts of the province are within the Indus Basin. A recent study examined the precipitation trends over the entire Indus Basin [25]. 


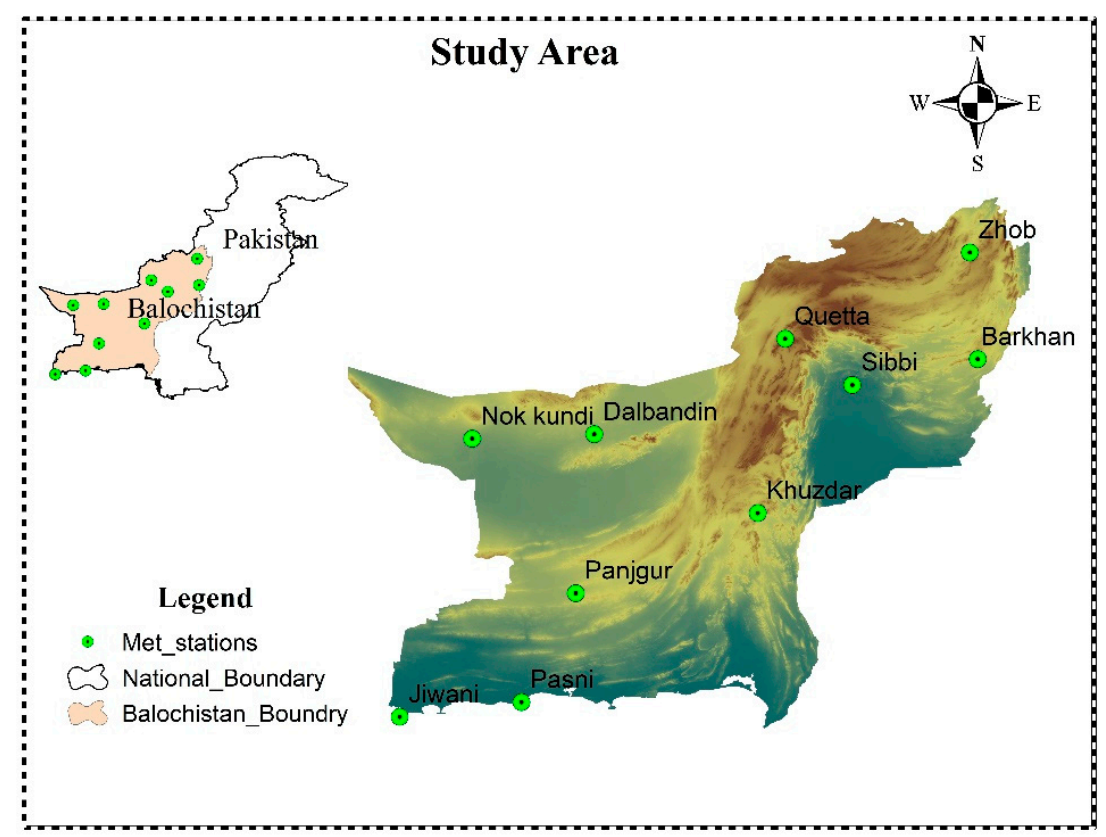

Figure 1. Map of Balochistan province, Pakistan.

\subsection{Methodology}

\subsubsection{Data Collection}

Long-term precipitation data is necessary for a better understanding of drought events. Therefore, 38 years of monthly rainfall data from 10 meteorological stations in the Balochistan region were obtained from the Pakistan Meteorological Department (PMD) for this study. The selection of gauge stations and the present study period (1980-2017) were based on rainfall data availability and location in this province.

\subsubsection{Standardized Precipitation Index}

SPI is a statistical tool [26], which only requires monthly precipitation data, and is recommended by the World Meteorological Organization for use in characterizing meteorological droughts worldwide [27,28]. Applying run theory [29] on the SPI series yields drought characteristics such as duration, severity, intensity, and peak, which can be analyzed for spatial patterns and temporal trends. SPI is considered a reliable indicator to study droughts because of its robustness and reliability [30]. The calculation of SPI with the monthly time-series precipitation data is based on fitting to an analytic probability distribution function, which was converted into a standardized normal distribution with zero as a mean and a unit standard deviation [26,31]. Time series of monthly precipitation was found to fit well by a gamma distribution [32]. In this study, three-month SPI is applied to historical precipitation data for the period of 1980-2017 in Balochistan.

\subsubsection{Trend Analysis}

The Mann-Kendall (M-K) test is commonly used to identify monotonic trends in climate data. It has advantages for hydro-meteorological time series, where outliers and missing values are often found. This non-parametric test measures monotonic trends in time series data without assuming a linear trend or a normal distribution [33].

In this study, the M-K test was used on the SPI dataset to identify whether precipitation is significantly increasing or decreasing. The null hypothesis of this test is that there is no trend, whereas the alternative hypotheses are an increasing or a decreasing trend. This approach is similar to that used in previous studies $[8,34]$. 


\subsubsection{Characteristics of Drought}

According to Reference [26], an event is identified as a drought episode if the values of SPI are constantly negative and reach -1.0 or less. The drought period starts in the first month when the SPI is less than -1.0 , and the dry event ends when SPI reaches positive values. A similar approach was used in the present study to characterize the drought. In this study, the -1 threshold value was set for the identification of drought conditions, with SPI at or below this threshold value used as the indicator of drought [35]. In addition, we assume in our present study that a drought started whenever the SPI value remained less than a set threshold $(\leq-1)$ for at least three consecutive months and finished when SPI rose above the set threshold $(>-1)$. Once the starting and ending of a dry period were calculated, other related drought indicators including duration, severity, peak, and intensity, were analyzed.

\section{Drought Indicators}

Drought intensity $\left(D_{I}\right)$ of an event is calculated by dividing the drought severity by its duration. Drought is considered more severe when the $D_{I}$ value is larger. Drought Peak $\left(D_{P}\right)$ is the lowest SPI value during a drought event [36]. The Drought Duration $\left(D_{D}\right)$ of an event is the number of months it lasts [37]. Drought severity $\left(D_{S}\right)$ is the sum of SPI during a drought event. The equations are:

$$
\begin{gathered}
D_{S}=\left|\sum_{J=1}^{D D} i n d e x_{J}\right| \\
D_{I}=\frac{D_{S}}{D_{D}}
\end{gathered}
$$

where $J$ represents a month, index $J$ shows value of SPI in $J$ month, and $D_{D}, D_{S}$, and $D_{I}$ denotes duration, severity, and intensity of a dry period, respectively.

\section{Results}

The classification of drought intensities was analyzed by SPI [26], as shown in Table 1. The three-month timescale of SPI represents moisture conditions in the short term and is used to analyze seasonal rainfall. Another advantage of using this index at a three-month time-scale is because of its correlation with soil moisture conditions in agricultural lands [24]. The SPI at each station was visualized in the following sections along with any statistically significant trends in SPI or in the characteristics of droughts.

Table 1. Classification of drought events based on values of Standard Precipitation Index (SPI).

\begin{tabular}{cc}
\hline SPI & Drought Categories \\
\hline 0 to -0.99 & Near normal \\
-1 to -1.49 & Moderately dry \\
-1.5 to -1.99 & Severely dry \\
-2 and less & Extremely dry \\
\hline
\end{tabular}

\subsection{Temporal Analysis of Meteorological Droughts}

Visualizing the SPI time series of each station, it was observed that all the 10 stations showed moderate, severe, and extreme droughts over the study period. For example, in Jiwani, which is the south-westernmost station, moderate drought events were seen in February for the years 1981, 1989, 2000, 2002, 2013, and 2016. Moderate droughts were also observed in March in the years 2000, 2001, 2002, 2007, and 2013 (Figure 2).

No extreme drought events were found in Dalbandin, Nok Kundi, and Pasni. Moreover, in Dalbandin, severe events were mostly observed in February, March, and April from 2000 to 2017 (Figure 3). The easternmost station of Barkhan faced more extreme drought events than the rest of 
the stations. The extreme droughts months were mostly from March to October in 2000 to 2004, 2009, 2016, and 2017 (Figure 4). Quetta, which is the most populated city in Balochistan, experienced three extreme droughts in March and April of 2000, 2004, and 2008. However, it faced moderate to severe droughts from December to July in different years (Figure 5).

Nok Kundi faced mostly moderate droughts starting in January and lasting until May (Figure 6). Pasni faced moderate droughts in the starting months of 1984, 1985, 1989, 2000 to 2002, 2006, and 2016 (Figure 7). In Zhob (Figure 8), extreme drought events occurred in March as well as in July to October. Six extreme drought events were observed at Khuzdar station, mostly from May to October, in the years 1996, 2001, 2002, 2004, 2009, and 2014 (Figure 9).

Furthermore, as can be seen in Figure 10, Panjgur faced only one extreme drought, in March of 1989 , and moderate and severe events were found in most of the years from January to July. In Sibbi (Figure 11), extreme drought events were also occurred mostly in March as well as from July to October.

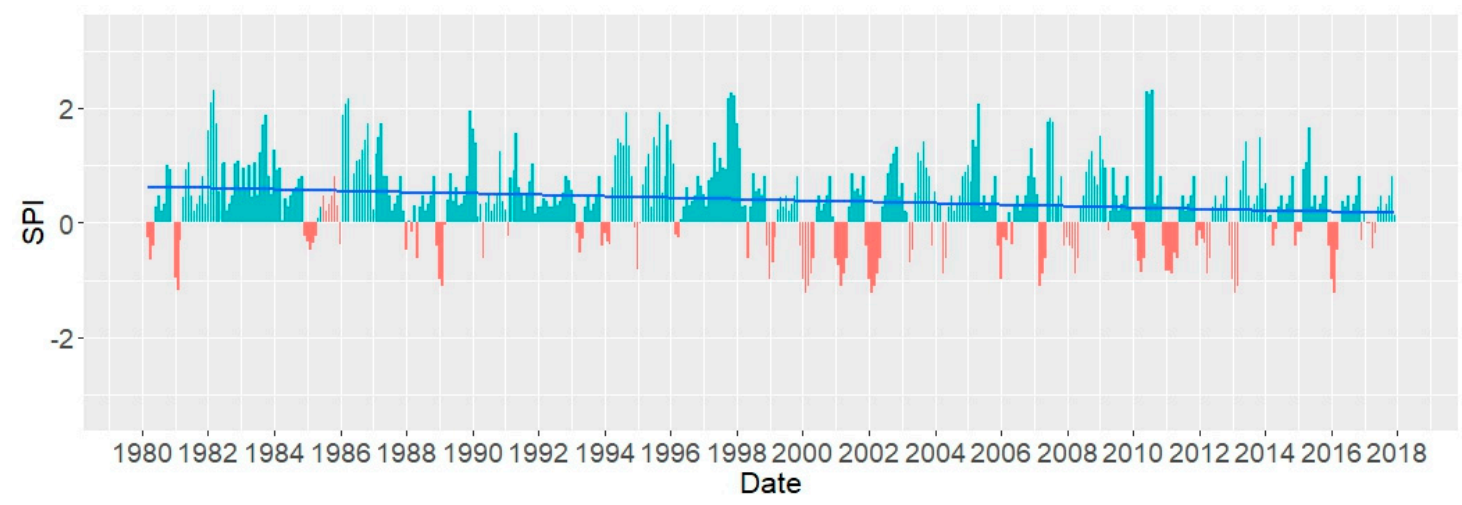

Figure 2. Three-month SPI of Jiwani station.

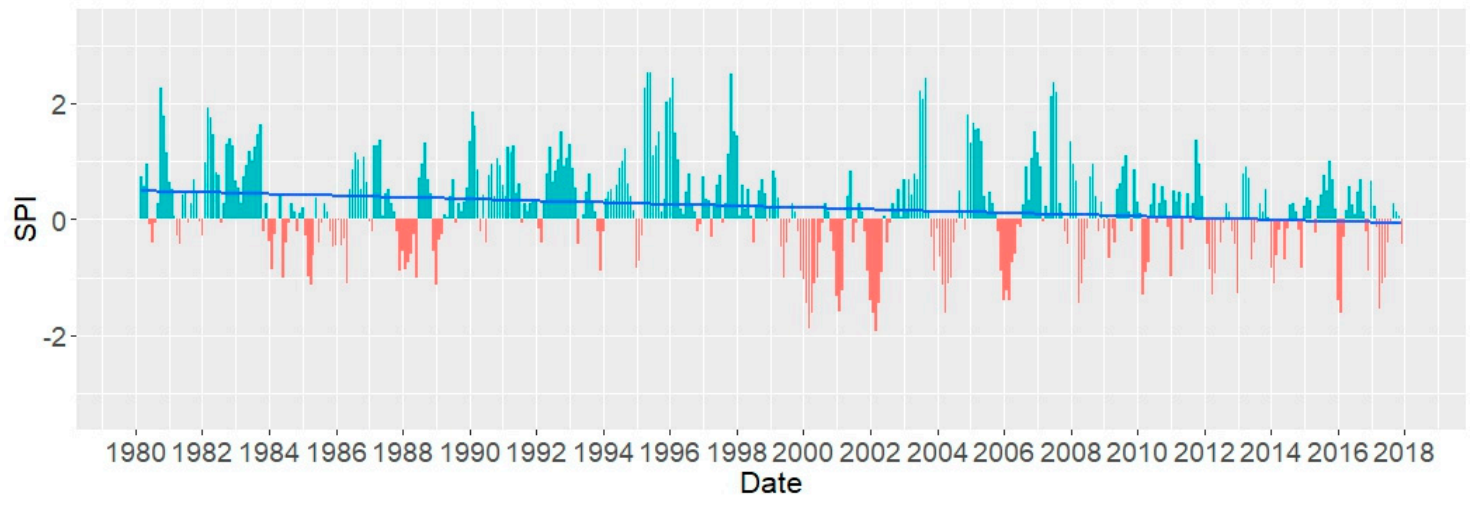

Figure 3. Three-month SPI of the Dalbandin station.

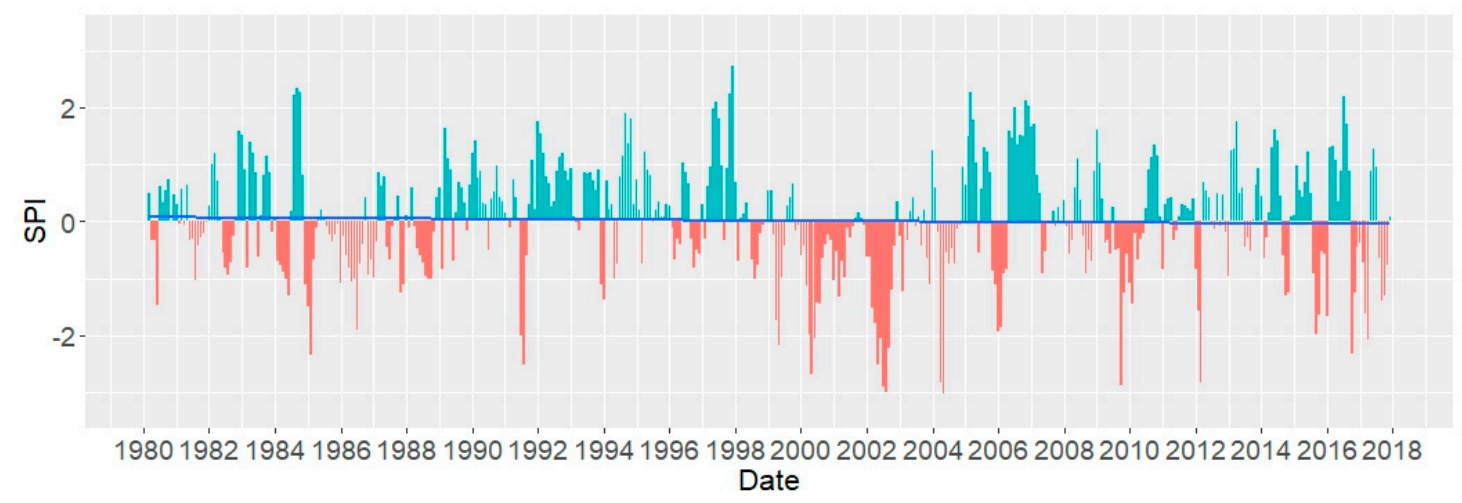

Figure 4. Three-month SPI of the Barkhan station. 


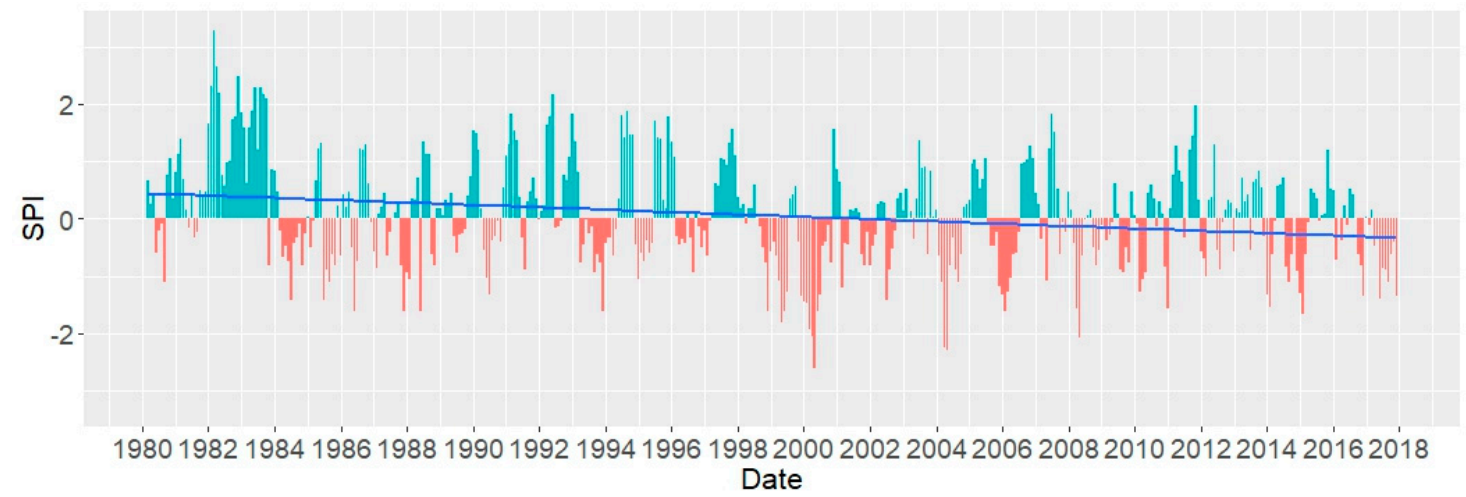

Figure 5. Three-month SPI of the Quetta station.

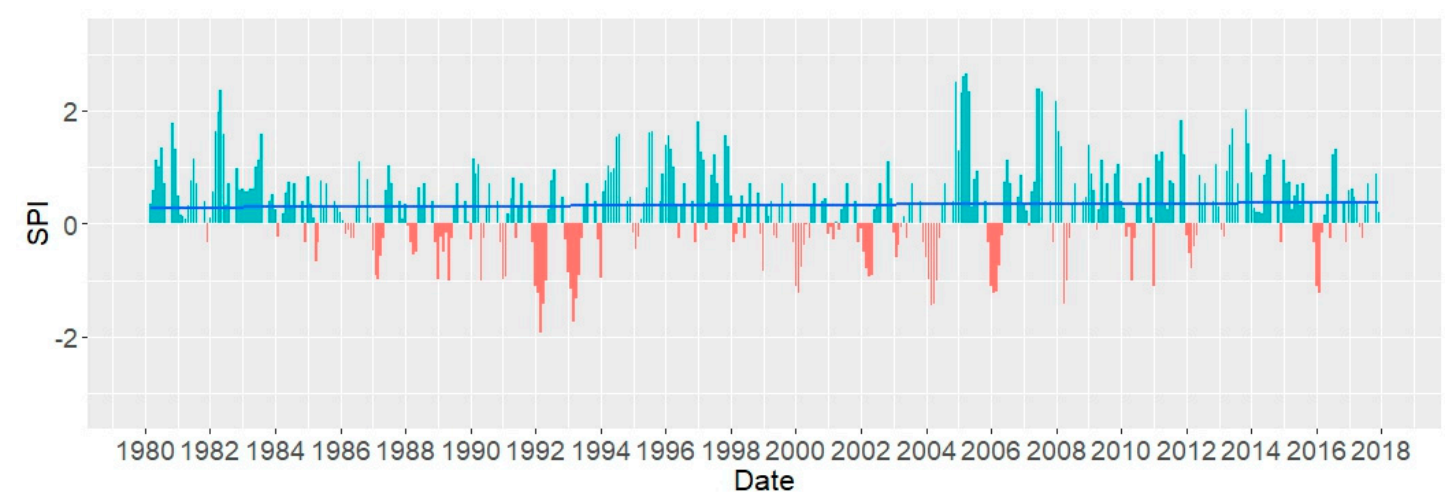

Figure 6. Three-month SPI of the Nok kundi station.

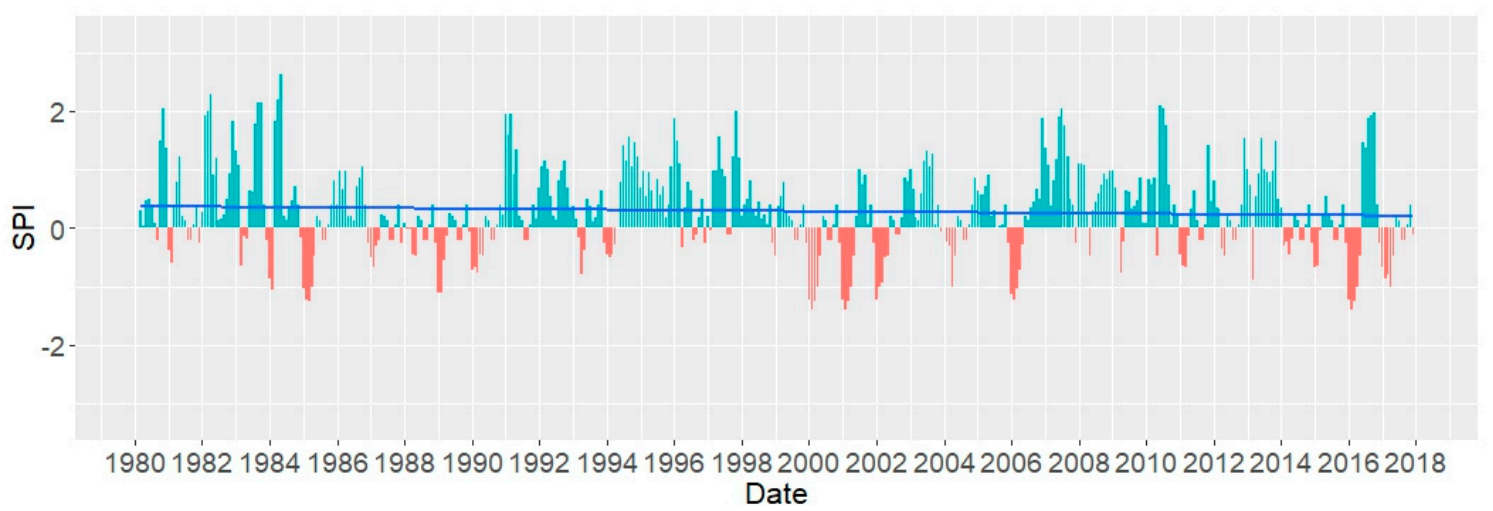

Figure 7. Three-month SPI of the Pasni station.

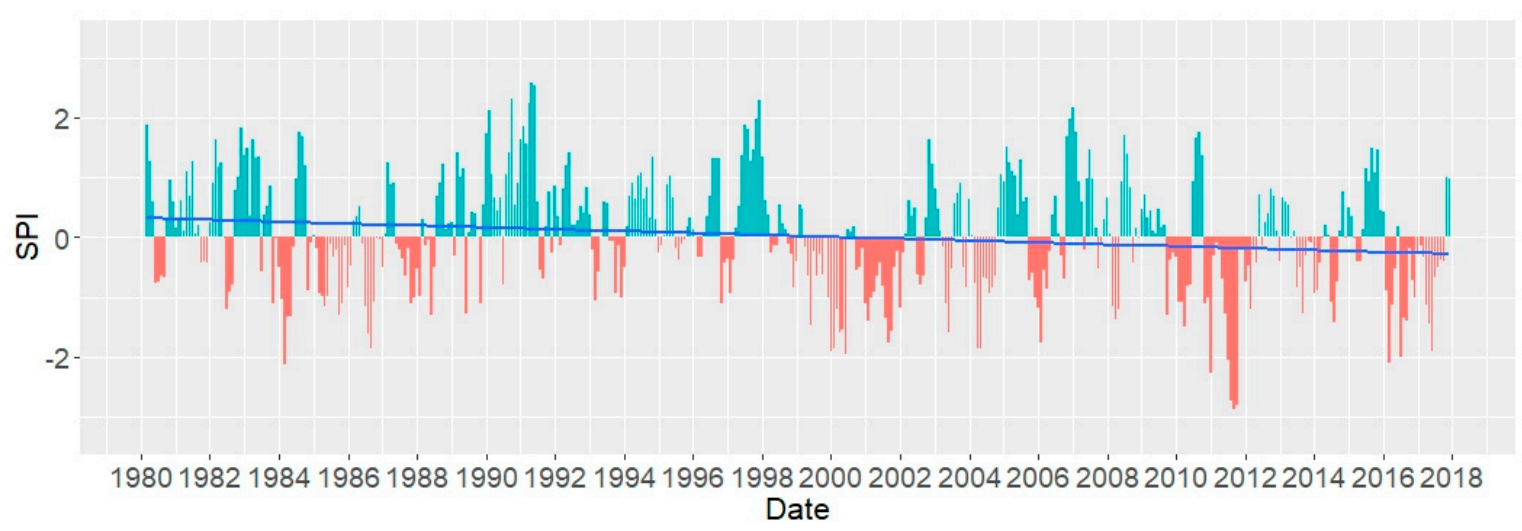

Figure 8. Three-month SPI of the Zhob station. 


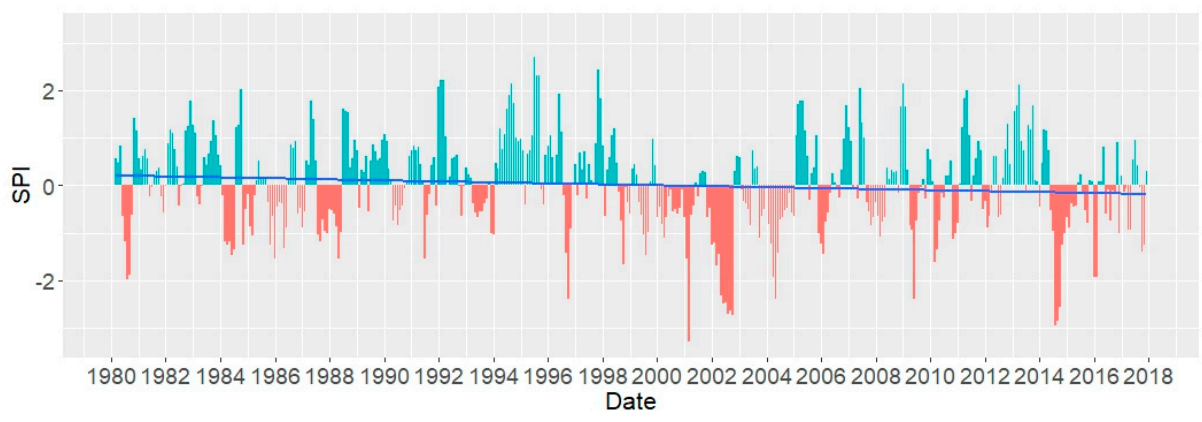

Figure 9. Three-month SPI of the Khuzdar station.

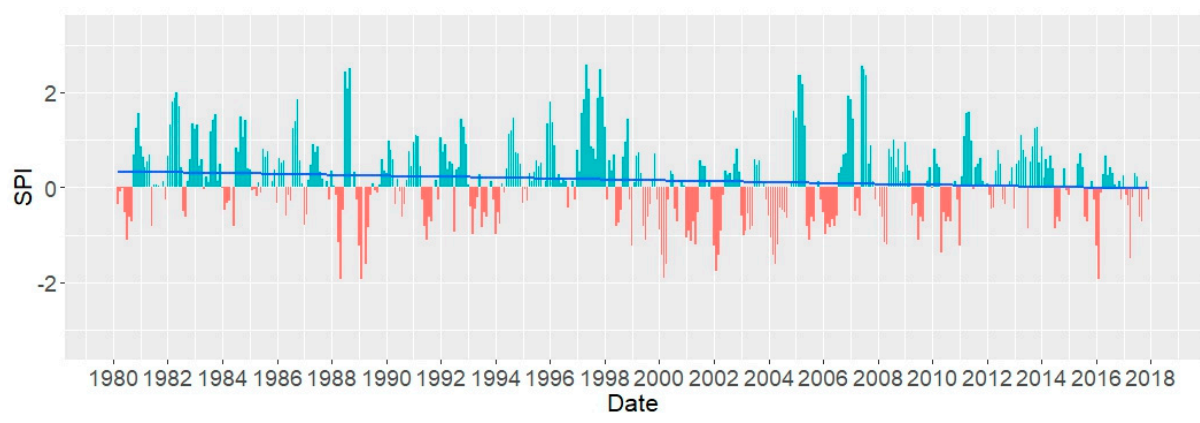

Figure 10. Three-month SPI of the Panjgur station.

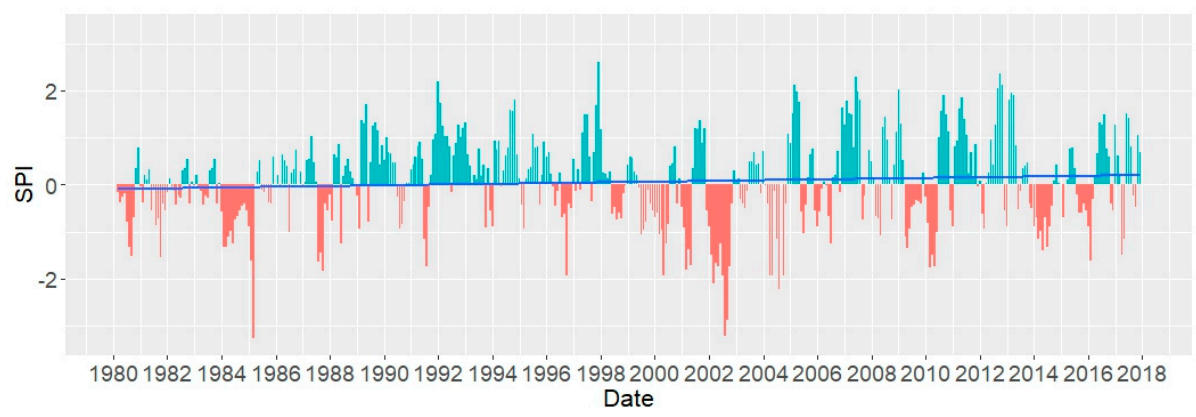

Figure 11. Three-month SPI of the Sibbi station.

\subsection{Analysis of Drought Trends}

The significance level at which the results of the Mann-Kendall test were interpreted was $p$-value 0.05. Statistically significant negative trends were seen at four out of ten stations for Dalbandin, Jiwani, Quetta, and Zhob where $p \leq 0.05$, as shown in Table 2, while no stations had a significant increasing trend. Therefore, based on these results, it can be safely said that the Balochistan region, on average, is experiencing a decreasing trend in precipitation.

Table 2. Results of Mann-Kendall trend test.

\begin{tabular}{ccc}
\hline Stations & $z$-Value & $p$-Value \\
\hline Barkhan & -0.4777 & 0.632 \\
Dalbandin & -2.1121 & 0.034 \\
Jiwani & -2.036 & 0.041 \\
Quetta & -2.061 & 0.039 \\
Khuzdar & -1.1063 & 0.268 \\
Nokkundi & 0 & 1 \\
Panjgur & -1.4835 & 0.137 \\
Pasni & -0.528 & 0.597 \\
Sibbi & 1.3326 & 0.182 \\
Zhob & -1.9864 & 0.046 \\
\hline
\end{tabular}




\subsection{Drought Indicators}

As observed from Figure 12a, the maximum drought duration $\left(D_{D}\right)$ at Barkhan station is 22 months (1999-2001) with drought severity $\left(D_{S}\right)$ being -18.61. The minimum $D_{D}$ was three months, which occurred in 1980, 1991, 2012, and 2014. At Dalbandin station, the maximum duration was 10 months (2000 and 2004), whereas the shortest drought lasted three months in the years 1984, 2010, 2013, and 2016. Khuzdar experienced 16 months drought duration started in January 2000 and ended in April 2001. Soon after a 12-month drought from November 2001 to October 2002, it experienced a 16-month drought from October 2003 to January 2005. It also experienced droughts lasting a minimum of three months in the years 1991 and 2007.

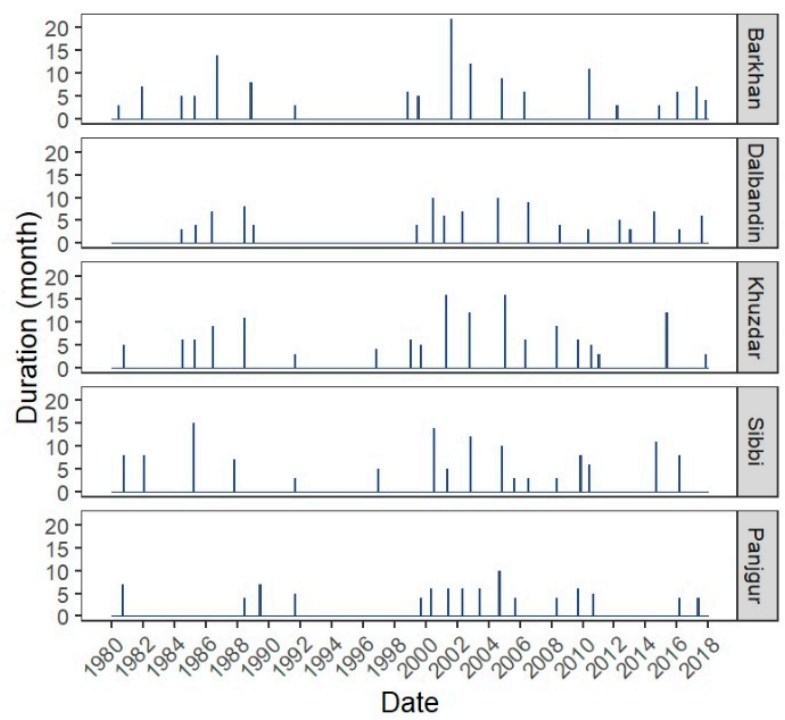

(a)

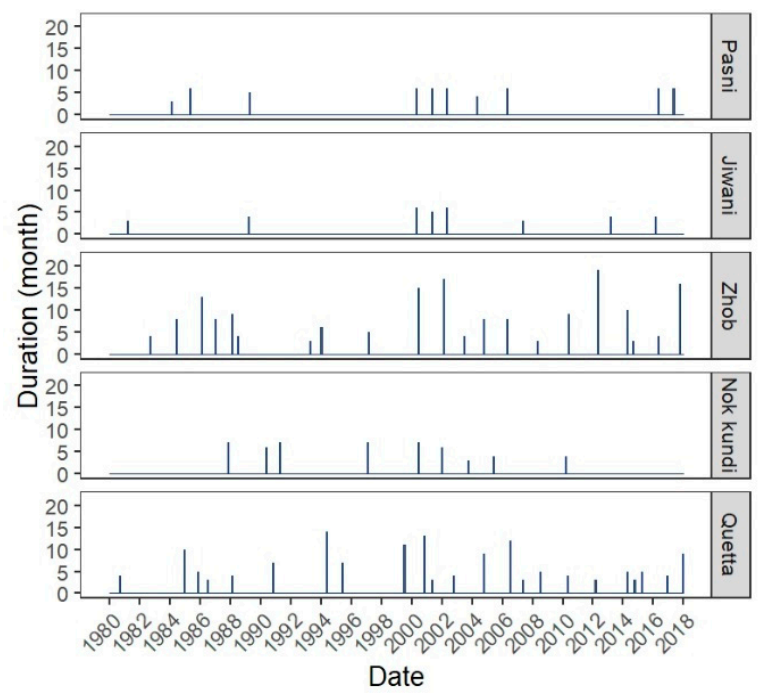

(b)

Figure 12. Drought durations at all stations.

Moreover, Jiwani and Pasni faced a maximum $D_{D}$ of six months and a minimum of three months Figure 12b. At Sibbi, Panjgur, and Zhob stations, droughts lasting 15, 10, and 19 months Figure 12a,b were observed with $D_{S}$ of $-15.7,-3.96$, and -13.80 Figure $13 a, b$. 


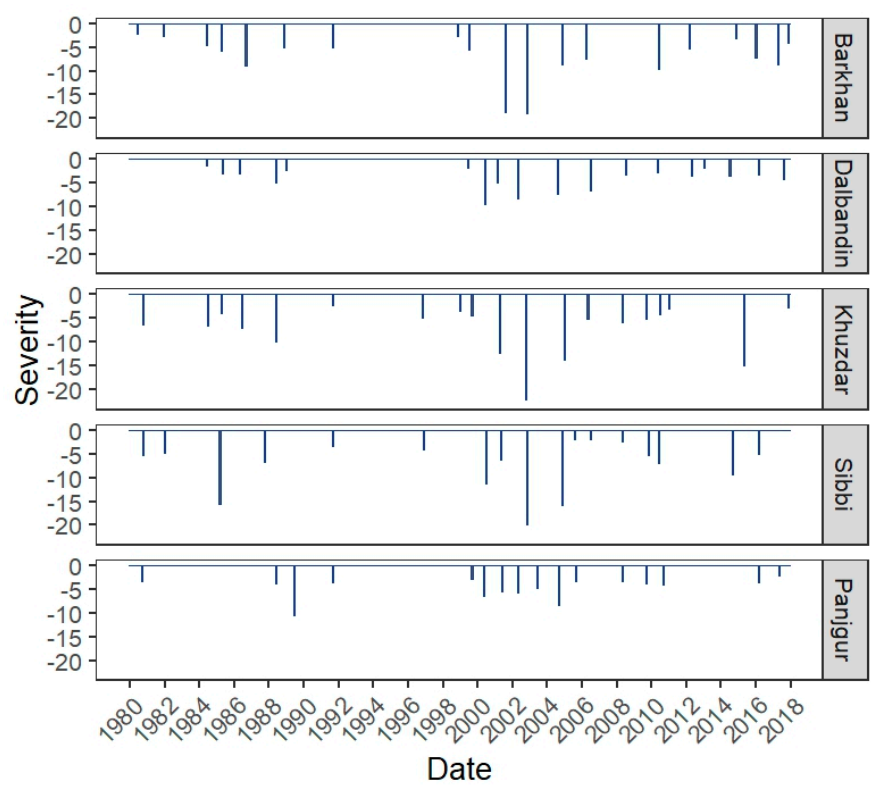

(a)

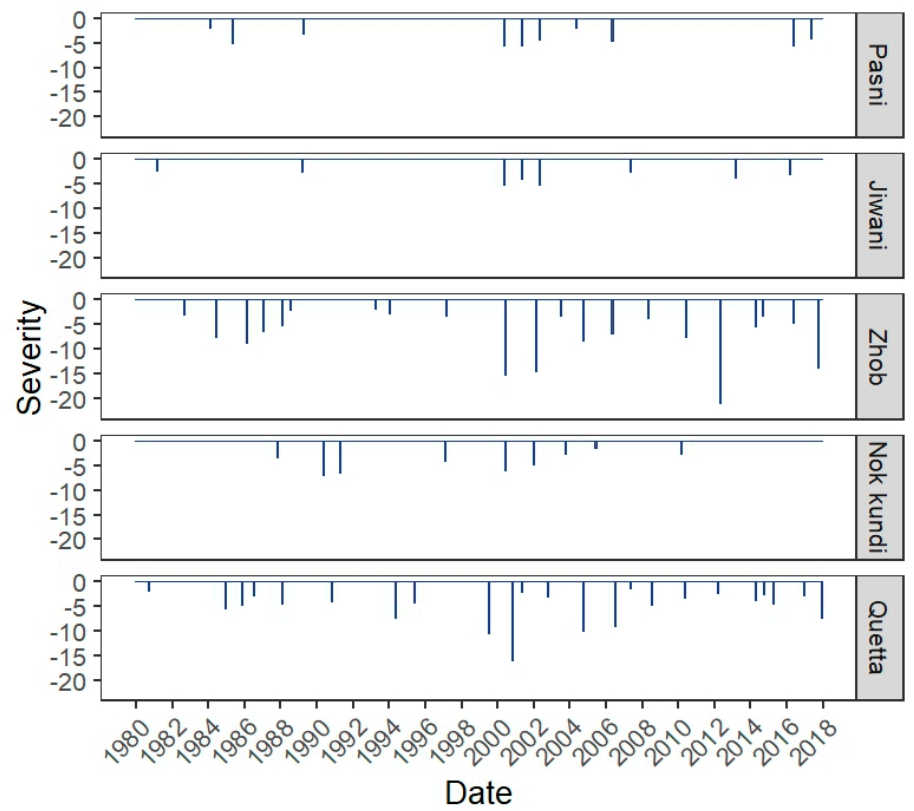

(b)

Figure 13. Drought severity at all stations.

However, among all the stations, Barkhan experienced the longest drought, which lasted for 22 months from 1999 to 2001. As seen from both Figure 12a,b and Figure 13a,b), a significant correlation was found in drought duration and severity. It indicates that the severe drought episodes were mostly prolonged.

As stated in Section 2.2.4, SPI values below the set threshold -1 represent drought characteristics. All the stations showed various drought intensity $\left(D_{I}\right)$ with below threshold -1 value except Pasni, and Jiwani Figure 14b. Looking at Figure 14b, it is evident that droughts in Pasni and Jiwani are less intense. Barkhan station experienced more intense droughts with the highest value of -2.28 in the year 2017 than the rest of the meteorological stations Figure 14a. From Figure 15a, the lowest drought peak $\left(D_{P}\right)$ value -5.63 recorded at Sibbi station in 2004 with its $D_{I}$ of -1.57 Figure 14a. 


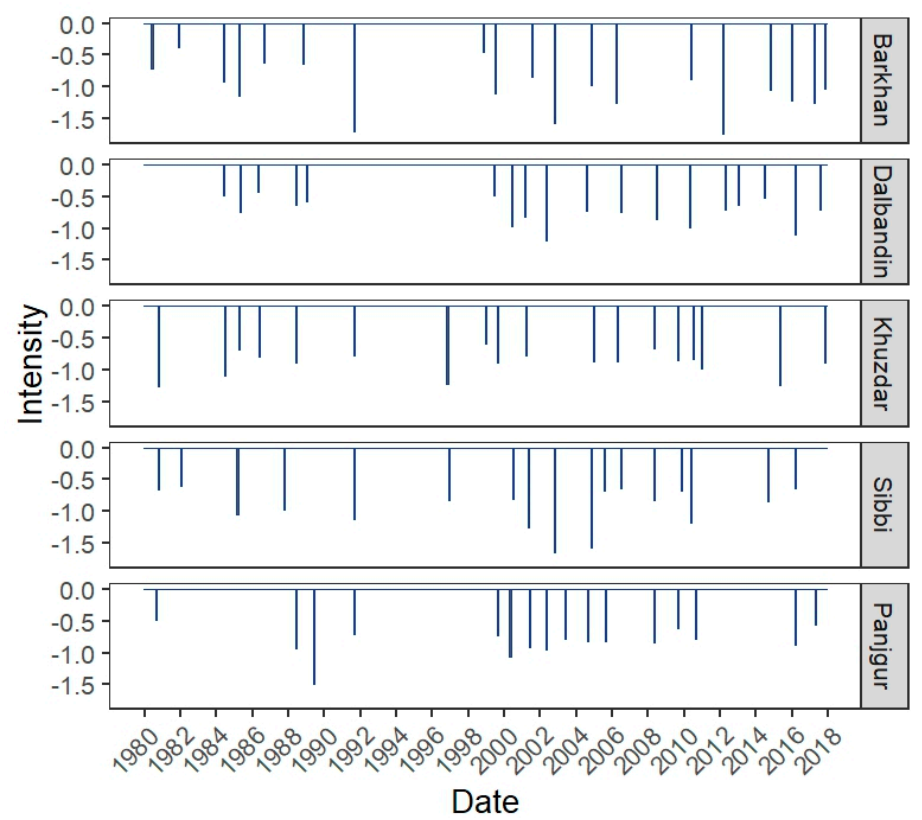

(a)

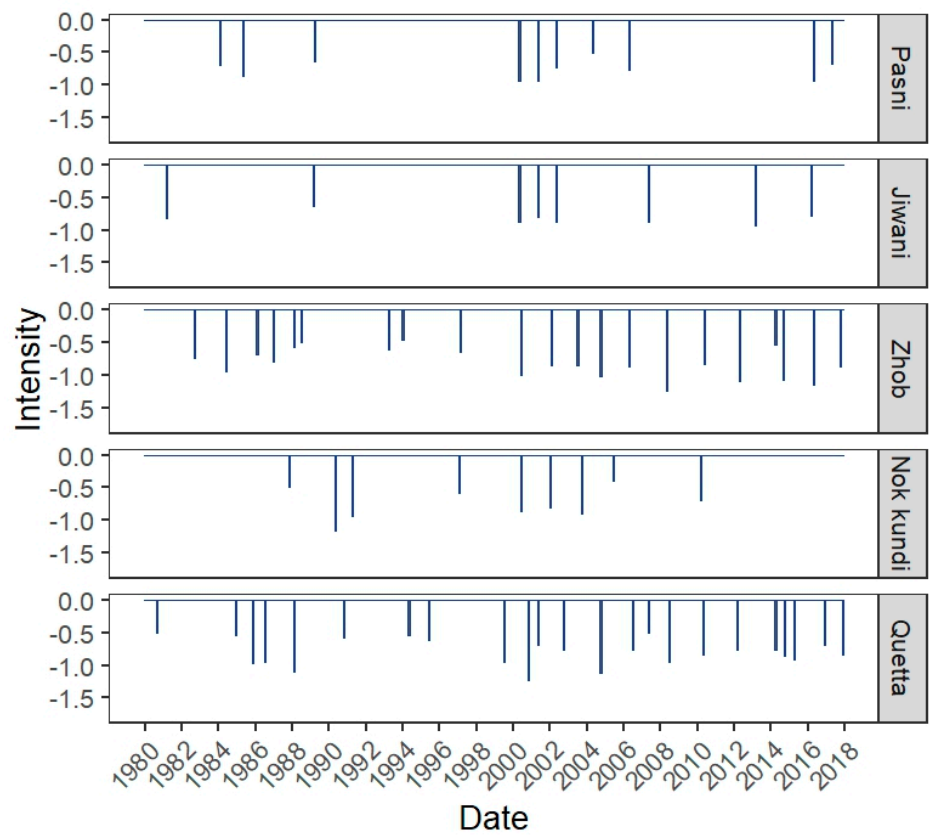

(b)

Figure 14. Drought intensity at all stations.

Moreover, the droughts that lasted at least 10 months with their characteristics are listed in Table 3. Barkhan had four drought events with a duration of at least 10 months. The first drought period began in late 1985 and finished in September 1986. This drought lasted 14 months with -0.62 intensity and severity of -8.81 . Soon after this, the Barkhan region experienced another long-term drought event of 22 months, which was started in November 1999 and ended in August 2001. Another drought with a worse peak of -3 occurred in this region from December 2001 to November 2002. A fourth drought event of 11 months began in August 2009 and finished in mid-2010. Dalbandin suffered two long drought events. One struck in late 1999 and the other one happened in late 2003. Khuzdar, Sibbi, and Quetta suffered from the highest number of dry (5) events having at least 10 months' duration. Khuzdar witnessed dry events in 1987, the early 2000s had a peak of -3.29 , late 2001 had the most 
severe peak of -22.08, that severe peak also occurred in late 2003 and mid-2014. Sibbi observed drought events in early 1984, mid-1999, late-2001, early 2004, and late 2013. The worst drought peak of -5.63 and highest intensity of -1.57 was observed in early 2004 , whereas the other drought events in early 1984 and late-2001 had peaks of -3.27 and -3.21 .

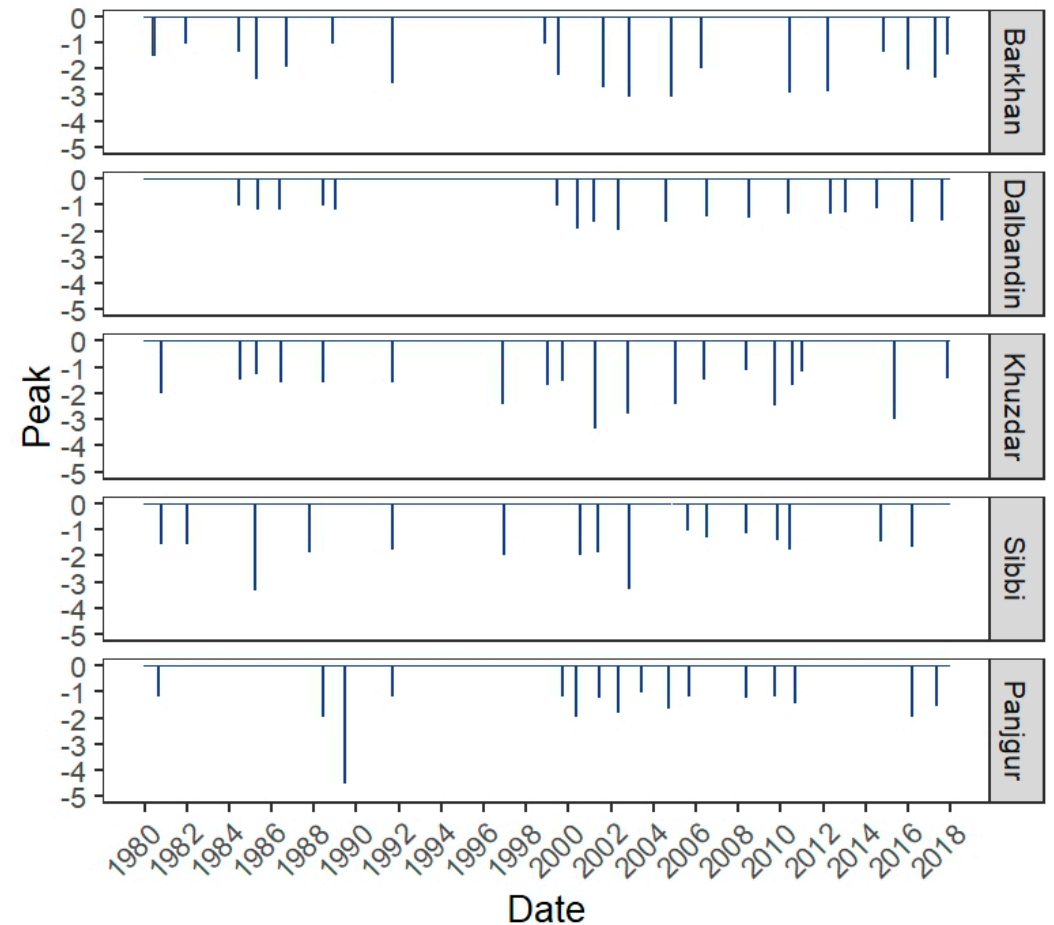

(a)

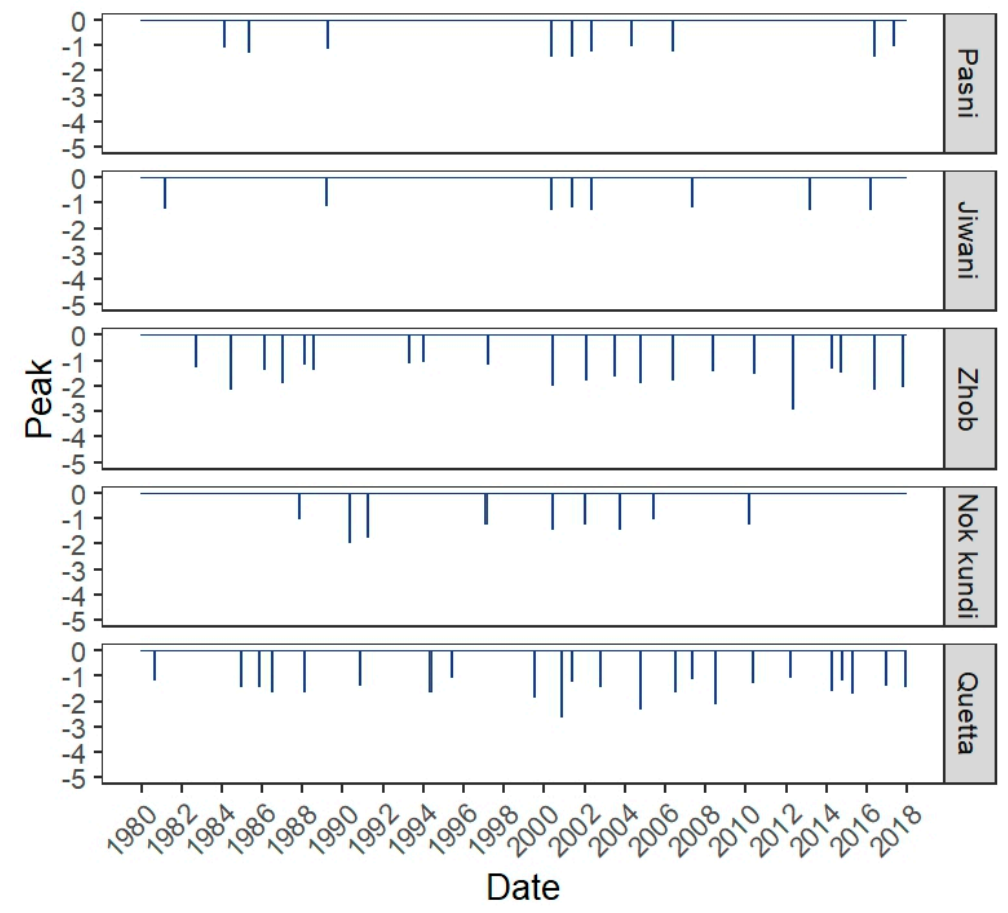

(b)

Figure 15. Drought peaks at all stations. 
Table 3. Droughts with durations of at least 10 months by the station with their characteristics.

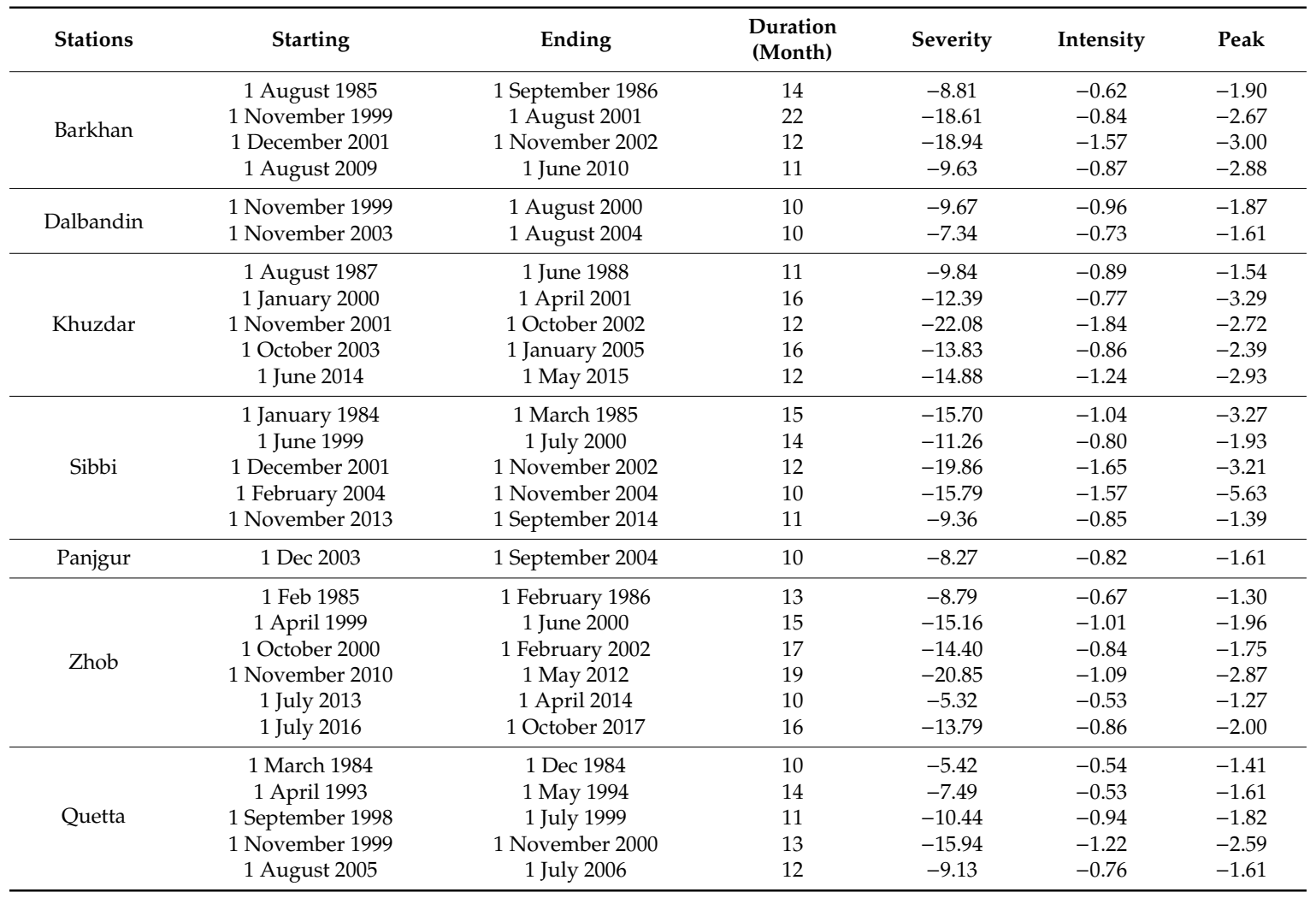

Panjgur had struck with one drought event of 10 months, with a peak of -1.61 in late-2003. The highest number of drought events of 10 months' duration were experienced in Zhob. Zhob witnessed such dry events in early 1985, mid-1999, late 2000, late 2010, mid-2013, and mid-2016. The most severe drought, with the severity of -20.85 and worst drought peak -2.87 was observed in late 2010 . The other two worst drought peaks of -1.96 and -2.00 were experienced in mid-1999 and mid-2016, respectively. At Quetta station, the first drought started in early 1984 and lasted for 10 months. The second drought event occurred in early 1993 and lasted for 14 months. Other witnessed years were mid-1998, late 1999, and mid-2005. The most worsen drought peaks of -1.82 and -2.59 , were observed in mid-1998 and late-1999. Overall, the longest dry period to have struck Balochistan was from 1998 to 2002.

\section{Discussion}

This present study focuses on precipitation for quantifying the characteristics of meteorological droughts using three-month SPI. The findings of this study revealed that all the 10 stations experienced summer and winter droughts throughout a recent 37-year period. The north-west of Balochistan province suffers from moderate to severe winter droughts frequently. Similar results were obtained in a study conducted by Ahmed [16]. The reason for winter droughts in northern areas of the province is the importance of westerly disturbances, whose intensity varies strongly from year to year, at or above $35^{\circ}$ north. By contrast, summer dry periods are due to the scarcity of monsoon precipitation. Meteorological stations, which are located in the north-east or east of the province, experience frequent extreme summer droughts, based on this present study. Summer dry periods affect the province's agriculture, while reducing its productivity by 50\% between 1998 to 2002 [12].

The analysis of precipitation (SPI) trends in the Balochistan province showed no trend in Nok Kundi, whereas, at Barkhan, Khuzdar, Panjgur, and Pasni, a non-significant decreasing trend was observed. A non-significant positive trend was seen only at Sibbi station. A significant negative trend was observed at four stations of Dalbandin, Jiwani, Quetta, and Zhob. Similar trends for Barkhan, Khuzdar, Pasni, and Sibbi were found in previous work by Ashraf and Routray [10]. Similarly, 
statistically decreasing trends for Quetta and Panjgur were reported in that study at a $10 \%$ and a 5\% confidence level. A decrease in precipitation from 1995-2013 was also found in the study of Iqbal [38] for Balochistan.

Moreover, the findings also revealed that moderate to extreme drought periods occurred at each station. Four of these periods, the mid-1980s to late 1980s, 1999-2000, late 2000, and early 2010, are particularly important because they occurred at seven stations for about 10 months. The drought around 1999-2000 has gained substantial attention, whereas the three other drought periods in the mid-1980s to late 1980s, in late 2000, and early 2010, have not been commonly reported.

In addition, the effects of a changing climate on the characteristics of drought is also notable, especially at Balochistan, where most of the stations demonstrate a negative trend in SPI. It may be concluded that frequent droughts can be expected in the future for the arid region of Balochistan. The region around Barkhan station experienced its worst drought starting in late 1999, which lasted for almost two years with its peak of -2.67 . Furthermore, its drought severity is also high with a value of -18.61 . The worst drought peak of value -5.63 was recorded in the Sibbi region in early 2004 with an intensity of -1.57 , the other worst peaks of -3.27 and -3.21 were also observed in the early 1984 and late-2001. Khuzdar, Sibbi, and Quetta were suffered from five dry events with at least 10 months' duration. Zhob experienced the highest number of dry episodes (six). Therefore, it may be concluded that Barkhan, Khuzdar, Sibbi, Quetta, and Zhob may show worsening climate change effects. Further studies could be done in these drought-prone regions to see how they are projected to change in the future.

The interrelationships between $D_{D}, D_{S}, D_{I}$, and $D_{P}$ are not consistent at each station, and it can be seen in Table 3. The $D_{S}(-22.08)$ and $D_{I}(-1.84)$ correlations are the highest at Khuzdar. The same correlation of $D_{S}$ with $D_{I}$ and $D_{P}$ was observed at Sibbi and Barkhan stations. For example, a drought event of the third-most severe $(-19.86)$ with the second-most intense $(-1.65)$ and third worst peak $(-3.21)$ were observed at Sibbi. While, at the Barkhan station, a drought event of the fourth most severe $(-18.94)$ with the third-most intense $(-1.57)$ and fifth worse peak $(-3)$ correlation was found. By looking at Barkhan and Zhob, the correlation of $D_{D}$ with $D_{\mathrm{S}}$ was found but with lesser intensities. For instance, Barkhan remains almost two years of the fifth most severe $(-18.61)$ drought event with lesser intensity (-0.84) and the second-most drought event (19) experienced by Zhob with the second-most severity (-20.85) and less intense (-1.09). It indicates that the severe drought episodes were mostly prolonged [39]. However, less correlation was found between $D_{S}$ with $D_{P}$ at Sibbi and Khuzdar stations. For example, the worst peak (-5.63) from all the stations was found at Sibbi and associated with relatively less severity $(-15.79)$ of a drought event. Khuzdar had the second-worst peak (-3.29), associated with a less severe $(-12.39)$ drought event.

Some findings of our study contradict the results of Jamro [8], which used the standardized precipitation evapotranspiration index (SPEI) to analyze the variability of dry periods in Pakistan. That study, based on gridded climate products, showed that northern parts of Balochistan experienced a larger number of shorter droughts with moderate severity, while southwest and central Balochistan experienced fewer long droughts with high severity. By contrast, our study finds that the stations in the northern or north-east region experience the longest droughts with moderate to high severity, while stations in the south-west or southern areas experience less duration droughts with moderate severity. The difference requires further investigation, but may reflect the limitations of gridded climate products in this heterogeneous area, and illustrates the importance of drawing on station data, when available, to provide the best guidance for water management.

\section{Conclusions}

For many decades, droughts have occurred in Balochistan province with destructive impacts. The absence of appropriate monitoring and mitigation measures for droughts in this area increases the vulnerability of the province's agriculture and economy to more destructive impacts. In this study, the characteristics of droughts are analyzed in terms of duration, severity, intensity, and peak. 
Drought events were analyzed through SPI. The M-K trend test was applied to identify statistically significant trends, finding that SPI has mostly decreased, suggesting that precipitation is decreasing, and that drought vulnerability may, therefore, be increasing.

Overall, this study has shown the variability of dry event characteristics at different gauges of Balochistan. However, the present study has some limitations. We considered the 3-month SPI timescale only, which is appropriate for observing short-term meteorological dry events. However, future studies may include 12-month and 24-month SPI to characterize long-term hydrologic drought impacts. In addition, more advanced indices such as Standardized Precipitation Evapotranspiration Index (SPEI) may be used to capture climate change effects. These, however, require additional meteorological data to compute, whereas the SPI needs only monthly precipitation.

Since the economy of Balochistan heavily depends on agriculture, the findings from this study support the suggestion that water resources management strategies are based on rainwater harvesting, smart irrigation techniques, or tools. Water-reuse techniques at the local level need to be adopted, according to the changing patterns of rainfall in the Balochistan province. Regions that suffered from moderate to extreme drought events frequently are expected to suffer at least equally for frequent and intense droughts in the future, which implies the need for proper drought mitigation planning and efficient management, according to the variations in rainfall patterns. Additionally, there is a need for projections to more thoroughly investigate the future pattern of dry periods in the framework of a changing climate.

Author Contributions: All authors have read and agree to the published version of the manuscript. Conceptualization, all authors. Methodology, all authors. Software and Visualization, F.N. Writing-original draft, F.N. Writing-review and editing, all authors.

Funding: The United States Agency for International Development through the U.S.-Pakistan Center for Advanced Studies in Water (USPCAS-W) and by the National Oceanic and Atmospheric Administration Educational Partnership Program with Minority-Serving Institutions-Cooperative Science Center for Earth System Sciences and Remote Sensing Technologies under the Cooperative Agreement Grant No. NA16SEC4810008 supported N.Y.K. In addition, authors would like to acknowledge the financial support for this study from the USPCAS-W, Mehran University of Engineering and Technology, Jamshoro, Pakistan established with the grant of the United States Agency for International Development (USAID). The contents are the sole responsibility of the authors and do not necessarily reflect the views of USPCAS-W, USAID, or the United States or Government of Pakistan.

Conflicts of Interest: The authors declare no conflict of interest.

\section{References}

1. $\quad$ Eckstein, D.; Hutfils, M.L.; Winges, M. Global Climate Risk Index 2019: Who Suffers Most From Extreme Weather Events? In Weather-Related Loss Events in 2017 and 1998 to 2017; Germanwatch Nord-Süd Initiative e.V: Bonn, Germany, 2018.

2. Patt, A.G.; Schröter, D. Perceptions of climate risk in Mozambique: Implications for the success of adaptation strategies. Glob. Environ. Chang. 2008, 18, 458-467. [CrossRef]

3. Unfccc.Int. Available online: https://unfccc.int/resource/docs/publications/impacts.pdf (accessed on 28 November 2019).

4. Schilling, J.; Vivekananda, J.; Khan, M.A.; Pandey, N. Vulnerability to environmental risks and effects on community resilience in mid-west Nepal and south-east Pakistan. Environ. Nat. Resour. J. 2013, 3, 27. [CrossRef]

5. Smit, B.; Skinner, M.W. Adaptation options in agriculture to climate change: A typology. Mitig. Adapt. Strateg. Glob. Chang. 2002, 7, 85-114. [CrossRef]

6. Mahessar, A.A.; Qureshi, A.L.; Siming, I.A.; Kori, S.M.; Dars, G.H.; Channa, M.; Laghari, A.N. Flash Flood Climatology in the Lower Region of Southern Sindh. Eng. Technol. Appl. Sci. Res. 2019, 9, 4474-4479.

7. Anjum, S.; Saleem, M.; Cheema, M.; Bilal, M.; Khaliq, T. An assessment to vulnerability, extent, characteristics and severity of drought hazard in Pakistan. Pak. J. Sci. 2012, 64, 138-143.

8. Jamro, S.; Dars, G.H.; Ansari, K.; Krakauer, N.Y. Spatio-temporal variability of drought in Pakistan using standardized precipitation evapotranspiration index. Appl. Sci. 2019, 9, 4588. [CrossRef] 
9. Ashraf, M.; Routray, J.K.; Saeed, M. Determinants of farmers' choice of coping and adaptation measures to the drought hazard in northwest Balochistan, Pakistan. Nat. Hazards 2014, 73, 1451-1473. [CrossRef]

10. Ashraf, M.; Routray, J.K. Spatio-temporal characteristics of precipitation and drought in Balochistan Province, Pakistan. Nat. Hazards 2015, 77, 229-254. [CrossRef]

11. Jairath, J. Droughts and Integrated Water Resource Management in South Asia: Issues, Alternatives and Futures; Sage Publications: Sauzendeaux, CA, USA, 2008.

12. Shahid, A.; Zahid, H.; Qureshi, A.S.; Rashida, M.; Mohammad, S. Drought mitigation in Pakistan: Current status and options for future strategies. IWMI Work. Paper 2004, 85. Available online: http://www.iwmi.cgiar. org/Publications/Working_Papers/working/WOR85.pdf (accessed on 8 February 2020).

13. Zahid, M.; Rasul, G. Changing trends of thermal extremes in Pakistan. Clim. Chang. 2012, 113, 883-896. [CrossRef]

14. IPCC. Climate Change 2014: Synthesis Report. Available online: https://www.ipcc.ch/site/assets/uploads/ 2018/05/SYR_AR5_FINAL_full_wcover.pdf (accessed on 24 September 2019).

15. Ahmed, K.; Shahid, S.; Nawaz, N. Impacts of climate variability and change on seasonal drought characteristics of Pakistan. Atmos. Res. 2018, 214, 364-374. [CrossRef]

16. Ahmed, K.; Shahid, S.; Bin Harun, S.; Wang, X.J. Characterization of seasonal droughts in Balochistan Province, Pakistan. Stoch. Environ. Res. Risk Assess. 2016, 30, 747-762. [CrossRef]

17. Ahmed, K.; Shahid, S.; Chung, E.S.; Wang, X.J.; Harun, S.B. Climate change uncertainties in seasonal drought severity-area-frequency curves: Case of arid region of Pakistan. J. Hydrol. 2019, 570, 473-485. [CrossRef]

18. Xie, H.; Ringler, C.; Zhu, T.; Waqas, A. Droughts in Pakistan: A spatiotemporal variability analysis using the Standardized Precipitation Index. Water Int. 2013, 38, 620-631. [CrossRef]

19. Adnan, S.; Ullah, K.; Gao, S. Characterization of drought and its assessment over Sindh, Pakistan during 1951-2010. J. Meteorol. Res. 2015, 29, 837-857. [CrossRef]

20. Khan, M.A.; Gadiwala, M.S. A Study of drought over Sindh (Pakistan) using standardized precipitation index (SPI) 1951 to 2010. Pak. J. Meteorol. 2013, 9, 15-22.

21. Hina, S.; Saleem, F. Historical analysis (1981-2017) of drought severity and magnitude over a predominantly arid region of Pakistan. Clim. Res. 2019, 78, 189-204. [CrossRef]

22. Adnan, S.; Ullah, K.; Shuanglin, L.; Gao, S.; Khan, A.H.; Mahmood, R. Comparison of various drought indices to monitor drought status in Pakistan. Clim. Dyn. 2018, 51, 1885-1899. [CrossRef]

23. Adnan, S.; Ullah, K.; Shouting, G. Investigations into precipitation and drought climatologies in South Central Asia with special focus on Pakistan over the period 1951-2010. J. Clim. 2016, 29, 6019-6035. [CrossRef]

24. Haroon, M.A.; Zhang, J.; Yao, F. Drought monitoring and performance evaluation of MODIS-based drought severity index (DSI) over Pakistan. Nat. Hazards 2016, 84, 1349-1366. [CrossRef]

25. Krakauer, N.Y.; Lakhankar, T.; Dars, G.H. Precipitation Trends over the Indus Basin. Climate 2019, 7, 116. [CrossRef]

26. McKee, T.B.; Doesken, N.J.; Kleist, J. The Relationship of Drought Frequency and Duration to Time Scales. In Proceedings of the 8th Conference on Applied Climatology; American Meteorological Society: Boston, MA, USA, 1993; Volume 17.

27. Heim, R.R., Jr. A review of twentieth-century drought indices used in the United States. Bull. Am. Meteorol. Soc. 2002, 83, 1149-1166. [CrossRef]

28. Keyantash, J.; Dracup, J.A. The quantification of drought: An evaluation of drought indices. Bull. Am. Meteorol. Soc. 2002, 83, 1167-1180. [CrossRef]

29. Yevjevich, V. An objective approach to definitions and investigations of continental hydrologic droughts. J. Hydrol. 1969, 7, 353.

30. Svoboda, M.; Hayes, M.; Wood, D. Standardized Precipitation Index User Guide; World Meteorological Organization: Geneva, Switzerland, 2012.

31. Edwards, D.C.; McKee, T.B. Characteristics of 20th century drought in the United States at multiple time scales. In Atmospheric Science Paper; Colorado State University Fort Collins: Fort Collins, CO, USA, 1997; Available online: https://apps.dtic.mil/dtic/tr/fulltext/u2/a325595.pdf (accessed on 8 February 2020).

32. Thom, H.C. A note on the gamma distribution. Mon. Weather Rev. 1958, 86, 117-122. [CrossRef]

33. Yue, S.; Pilon, P.; Cavadias, G. Power of the Mann-Kendall and Spearman's rho tests for detecting monotonic trends in hydrological series. J. Hydrol. 2002, 259, 254-271. [CrossRef] 
34. Samo, S.R.; Bhatti, N.; Saand, A.; Keerio, M.A.; Bangwar, D.K. Temporal analysis of temperature and precipitation trends in Shaheed Benazir Abad Sindh, Pakistan. Eng. Technol. Appl. Sci. Res. 2017, 7, 2171-2176.

35. Bae, S.; Lee, S.H.; Yoo, S.H.; Kim, T. Analysis of Drought Intensity and Trends Using the Modified SPEI in South Korea from 1981 to 2010. Water 2018, 10, 327. [CrossRef]

36. Spinoni, J.; Naumann, G.; Vogt, J.V.; Barbosa, P. The biggest drought events in Europe from 1950 to 2012. J. Hydrol. Reg. Stud. 2015, 3, 509-524. [CrossRef]

37. Spinoni, J.; Naumann, G.; Carrao, H.; Barbosa, P.; Vogt, J. World drought frequency, duration, and severity for 1951-2010. Int. J. Climatol. 2014, 34, 2792-2804. [CrossRef]

38. Iqbal, M.F.; Athar, H. Variability, trends, and teleconnections of observed precipitation over Pakistan. Theor. Appl. Climatol. 2018, 134, 613-632. [CrossRef]

39. Deo, R.C.; Byun, H.R.; Adamowski, J.F.; Begum, K. Application of effective drought index for quantification of meteorological drought events: A case study in Australia. Theor. Appl. Climatol. 2017, 128, 359-379. [CrossRef]

(C) 2020 by the authors. Licensee MDPI, Basel, Switzerland. This article is an open access article distributed under the terms and conditions of the Creative Commons Attribution (CC BY) license (http://creativecommons.org/licenses/by/4.0/). 